\begin{tabular}{|c|c|c|}
\hline 8 & e & $\begin{array}{l}\text { ISSN: 1991-2951 (Print) } \\
\text { ISSN: 2091-2781 (Online) }\end{array}$ \\
\hline $\begin{array}{l}\text { Nature Conservation \& } \\
\text { Health Carre Council } \\
\text { Biratnagar, Nepal }\end{array}$ & Journal homepage: http://nepjol.info/index.php/ON & (c) $\mathrm{Br}_{\mathrm{BY}}(\mathrm{N}$ \\
\hline
\end{tabular}

\title{
Herpetofaunal diversity in Manaslu Conservation Area, Nepal
}

\author{
Ganesh Kumar Pokhrel and Sudeep Thakuri* \\ Companions for Amphibians and Reptiles of Nepal (CARON), NPC-491, Kathmandu, Nepal \\ "E-mail: sthakuri@hotmail.com
}

\begin{abstract}
Herpetofauna is the least studied subject in the Nepal Himalaya. Most of the studies in wildlife are focused on mammals and birds. This paper presents the results of the herpetofauna survey in Manaslu Conservation Area in the Central Nepal, conducted with the aim of establishing the baseline on herpetofauna species diversity. The study recorded 16 species of herpetofauna, indicating a highly potential abundance of herpetofauna in the region. The study is first of its kind in establishing the baseline. The information, thus, obtained can be useful for implementing a biodiversity monitoring activities, and current and future conservation efforts. The study also underlines a need of an extensive study of herpetofauna in this region.
\end{abstract}

Key words: Amphibian, Inventory, Monitoring, Reptile, Himalaya

DOI: http://dx.doi.org/10.3126/on.v14i1.16448

Manuscript details: Received: 05.08.2016 / Accepted: 25.08.2016

Citation: Pokhrel, G.K. and S. Thakuri 2016. Herpetofaunal diversity in Manaslu Conservation Area, Nepal. Our Nature 14(1): 99-106. DOI: http://dx.doi.org/10.3126/on.v14i1.16448

Copyright: () Pokhrel and Thakuri 2016. Creative Commons Attribution-NonCommercial 4.0 International License.

\section{Introduction}

Herpetofauna represents species of reptiles and amphibians, like snakes, lizards, frogs, turtles, alligators, and salamanders. Amphibians and reptiles are considered as beneficial faunal group due to the unique role they play in the ecosystem (Chaudhary, 1998; Shrestha, 2001). They have a very significant function in the food chain and control a wide variety of agricultural pests. In recent decades, Amphibians and reptiles population have suffered widespread declines and extinctions (Blaustein and Wake, 1995; Kiesecker et al., 2001). Limited dispersal ability may further increase the vulnerability of amphibians and reptiles to changes in climate. Slight changes in water level in breeding ponds can trigger repro- 
ductive failure and, in a single year, cause a severe drop in the population size of shortlived species; persistent changes can lead to extinctions of species (Arau jo et al., 2006). Amphibian decline problem is a serious threat and reptiles appear to be in even greater danger of extinction worldwide (Gibbons et al., 2000). So, the assessments of amphibian and reptile diversity require exploration of previously unvisited areas, comprehensive surveys of poorly known areas, and revisiting of localities that have not been assessed in the last decade (Parra et al., 2007).

Nepal is extremely rich in habitat diversity, therefore a variety of habitats occurring in the Tropical to Nival zone are available for the native amphibians and reptiles. Based on their distribution and habits they utilize forests, grasslands, alpine meadows, trees, tunnels, cliffs, rocks, different aquatic bodies, agricultural lands and even houses as macro and microhabitats. Nepalese herpetofauna have a wide range of vertical (60-5,490 m) and horizontal (Mechi to Mahakali) distribution. Studies to date have confirmed that Nepal's herpetofauna embraces Palearctic, Oriental, Indo-Chinese and Himalayan elements (Shah and Tiwari, 2004). Fourteen species of herpetofauna are endemic to Nepal. Seventeen species of the herpetofauna are nationally threatened, of which six species are globally threatened (ICIMOD and MOEST-GON, 2007). A recent publication - Amphibians and Reptiles of Nepal, edited by Schleich and Kastle (2002) - provides an account of 50 amphibians and 123 reptiles. The herpetofauna in Nepal is relatively richer compared to other South Asian countries-well over 206 species and sub-species, including 59 amphibian species of which 15 are listed as globally threatened. However, Amphibian and reptiles of Nepal face severe threat of extinction. Major threats include rapid deforestation, soil and water pollution, land use changes, habitat loss and unplanned resource extraction. As herpetofauna is the poorly studied group in the country, their present status is also poorly known (CEPF, 2005), however according to IUCN Global Amphibian Assessment 2006, Nepal has $4 \%$ endemic species and the species composition had reduced compared to 2001 IUCN checklist (Molur, 2008). Very few species have been described from disturbed habitats, indicating a diminished species composition when compared with the original habitat (Molur, 2008). And, from a conservation point of view also, herpetofauna conservation efforts have been limited (Shah and Tiwari, 2004; Rai et al., 2006). Even these days all snakes (reptile) are considered to be poisonous and killed at sight. The tendency of indiscriminate exploitation of amphibians and reptiles species in the country has threatened the survival of some of the species so much (Shah, 1995).

In this context, a brief survey of herpetofauna has been conducted to explore their diversity, identify the species composition and assemblage and to sensitize the conservation efforts in in Manaslu Conservation Area (CA), Nepal. Additionally, the habitat situation and species association analyses are expected to add a new dimension in herpetological research in Nepal. Further, it is expected to fulfill the gap in herpetological species and site conservation point of view in Nepal as no scientific exploration of herps has been conducted so far in the area. 


\section{Study area}

The study area (longitude 84.48 to $85.20 \mathrm{E}$; latitude 28.34 to $28.75 \mathrm{~N}$ ), Manaslu CA (Fig. 1), was declared as a conservation area in 1998. It covers 7 Village Development Committees of Gorkha district in Central Nepal, with an area of $1,663 \mathrm{~km}^{2}$, ranging from 1360 to $8163 \mathrm{~m}$ in altitude. The

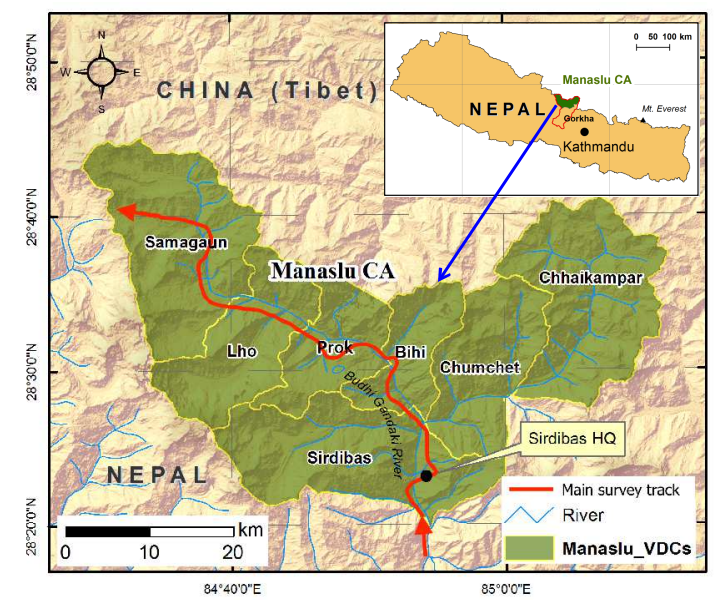

Figure 1. Location of Manaslu Conservation Area (CA) with the hill shade in the background

area is bordering the Annapurna Conservation Area to the west, the Tibetan part of China to the north and east, and the Ghyachok, Warpak, Uhiya, and Kerauja VDCs of Gorkha district to the south. The region harbors a mosaic of habitats for various species of wildlife. About 2,000 species of plants, 33 mammals, 110 birds, and 11 butterflies in 11 types of forests reported from the area (NTNC, 2016). As Manaslu CA covers mountain areas, the mountain biodiversity is not only a scientific theme of high interest, but also is perhaps the best indicator value of the integrity of mountain ecosystem (Körner, 2002). The climate variation in term of temperature, precipitation, and humidity is clearly noticeable with in a short latitudinal difference. The climate of the region ranges from the subtropical in the south (mean around $30^{\circ} \mathrm{C}$ in the summer and $10^{\circ} \mathrm{C}$ in the winter) to extremely cold alpine and nival in the north (below freezing point). As a consequence of physical heterogeneity of the mountains and climatic conditions, the mountain regions typically possess higher levels of biodiversity than plains, making it possible to conserve large amounts of diversity in relatively small areas (Lafon, 2004).

\section{Materials and methods}

This study was mainly based on the field survey of the Manaslu CA. Stream survey and trail survey was conducted. Random transect method has been applied in order to sampling in the area for intensive study. In each transect along the forest trail and streams two persons walked covering a distance of $5 \mathrm{~m}$ on both sides from the south to Northeast of the CA (Fig. 1) Opportunistic survey has also be conducted in other parts from transect lines based on (Gardner and Fitzherbert, 2007). Amphibians and reptiles were surveyed by using hand picking (using equipment for handling the reptiles and amphibians) in the sites (Fig. 2). For noc turnal survey a torch beam was used to locate the animal (Behangana and Arusi, 2004). Species caught during survey were

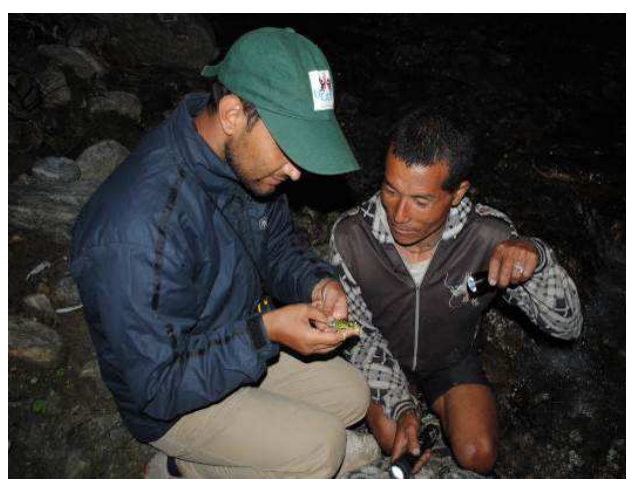

Figure 2. Identification of species at the site. 
identified on spot using field guide of Shah and Tiwari (2004) and released in-situ. The species encounter locations were recorded by using Garmin eTrex-10 Handheld GPS. The field activities were completed with a two weeks of survey in September, 2010.

The local residents were also contacted to collect information regarding herps in the area. Colored photographs from field manual of the potential amphibians and reptiles of the area were displayed to the local residents and asked to explain the features.

\section{Results and discussion Species inventory}

Altogether 16 species of herpetofauna (7 amphibians and 9 reptiles) were recorded in the Manaslu CA (Plates 1-2). Among them, 12 (5 amphibians and 7 reptiles) were recorded through direct observation and other 4 species were verified through literature (Shrestha, 2001; Tab. 1). Table 2 and Table 3 below shows the list of herps recorded through direct observation in the area. Laudakia tuberculata $(>100)$ is most abundant species in the area followed by Duttaphrynus microtympanum (11), Asymblepharus sikimmensis (9), Mabuya carinata (7), Duttaphrynus stomaticus (6), Amolops formosus (5), and others.

According to local people Paa blanfordii and Paa liebigii are also found in the streams of Phillim and Dyang areas (Table $1)$. We have made several attempts to observe these species, but we were unable to record during the field. Local people suggested to make the field visit in May-July to record these species from the area when streams have less amount of water. Species records were also made through local information and communication with conservation area staff and expert.

\section{Species composition and assemblage}

We recorded Bufo species (D. himalayanus, $D$. microtympanum, and D. stomaticus) mainly from settlement areas, agricultural land and forest areas. Paa (O. sikimensis) and Amolops species were recorded from small streams of the areas. We observed Laudakia tuberculata everywhere in the trail from Jagat (starting point of MCA) to Prok. In Phillim, we found the highest number of $L$. tuberculata. They were common in cultivated land, wall of houses, rocks etc in this place. Most of the amphibian species were found in trails and streams of Phillim, Nyak, and Dyang areas. After Lihi $(2,927 \mathrm{~m})$, we didn't find any species up to Larke $(5,106 \mathrm{~m})$, the heighted location survey. However, an intensive study is necessary in these areas as we just made trail survey. We didn't make any transect survey and stream survey without any evidence of herpetofauna occurrence from local people in the area.

Based on the GPS positions recorded during species survey in the field, the distributions of herps in the areas are demonstrated in the map below (Fig. 3).

\section{Conclusion}

The survey of herpetofauna in Manaslu CA has been conducted within short period of time. Within this short period of time we are able to record 16 species of herpetofauna with other important information in the area so, the area is highly potential for herpetofauna studies. People consume Paa frog as a food. We have recorded Paa frogs (such as, $P$. blanfordii, $P$. liebigii, $O$. sikimensis) that people used as food in the area (Plate 2). Phillim, Nyak, and Dyang area have high density of frogs. We have recorded all types in the list from these areas. 

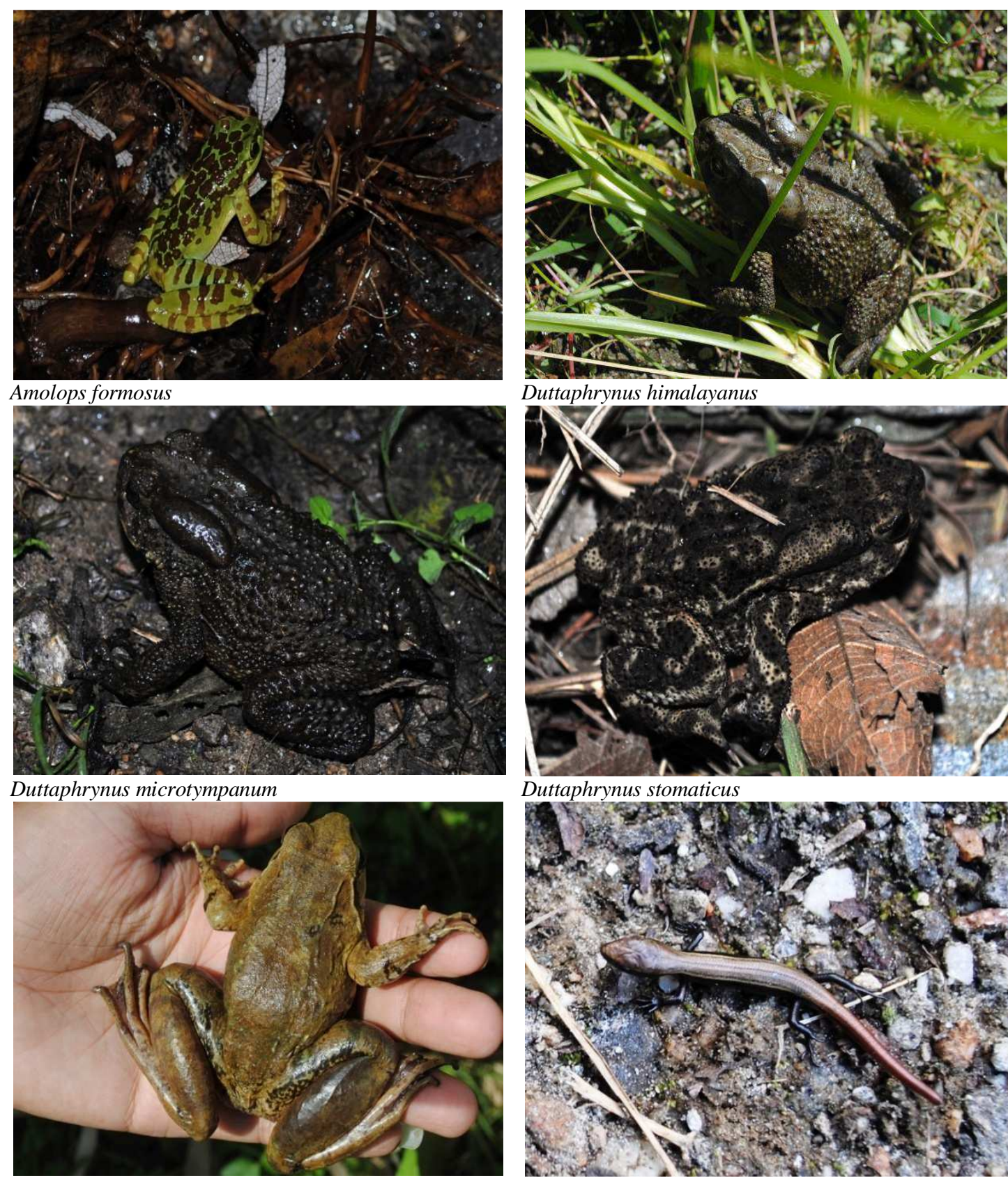

Duttaphrynus himalayanus

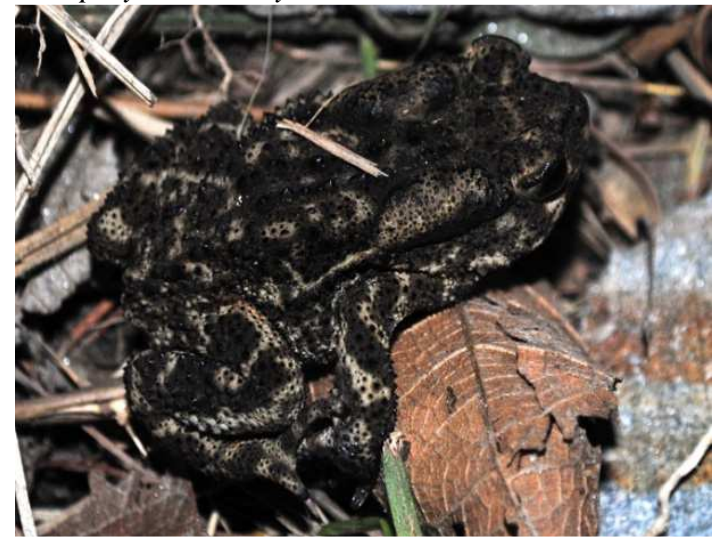

\section{Duttaphrynus stomaticus}

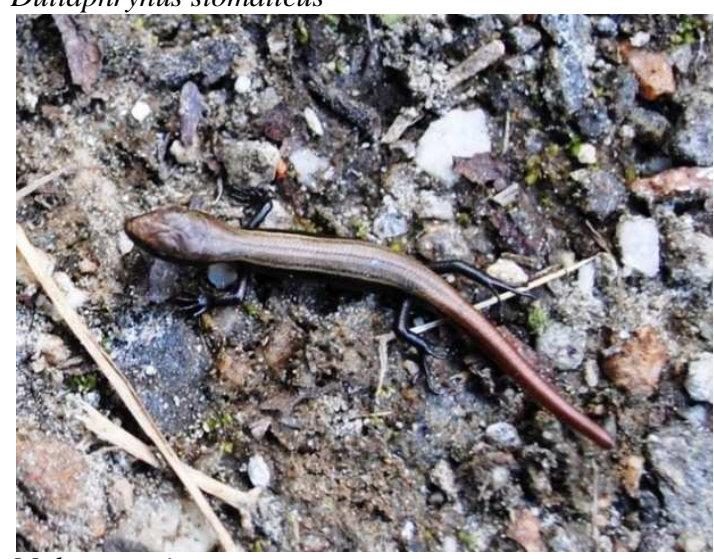

Ombrana sikimensis Mabuya carinata

Plate 1. Herpetofauna recorded from Manaslu Conservation Area. 

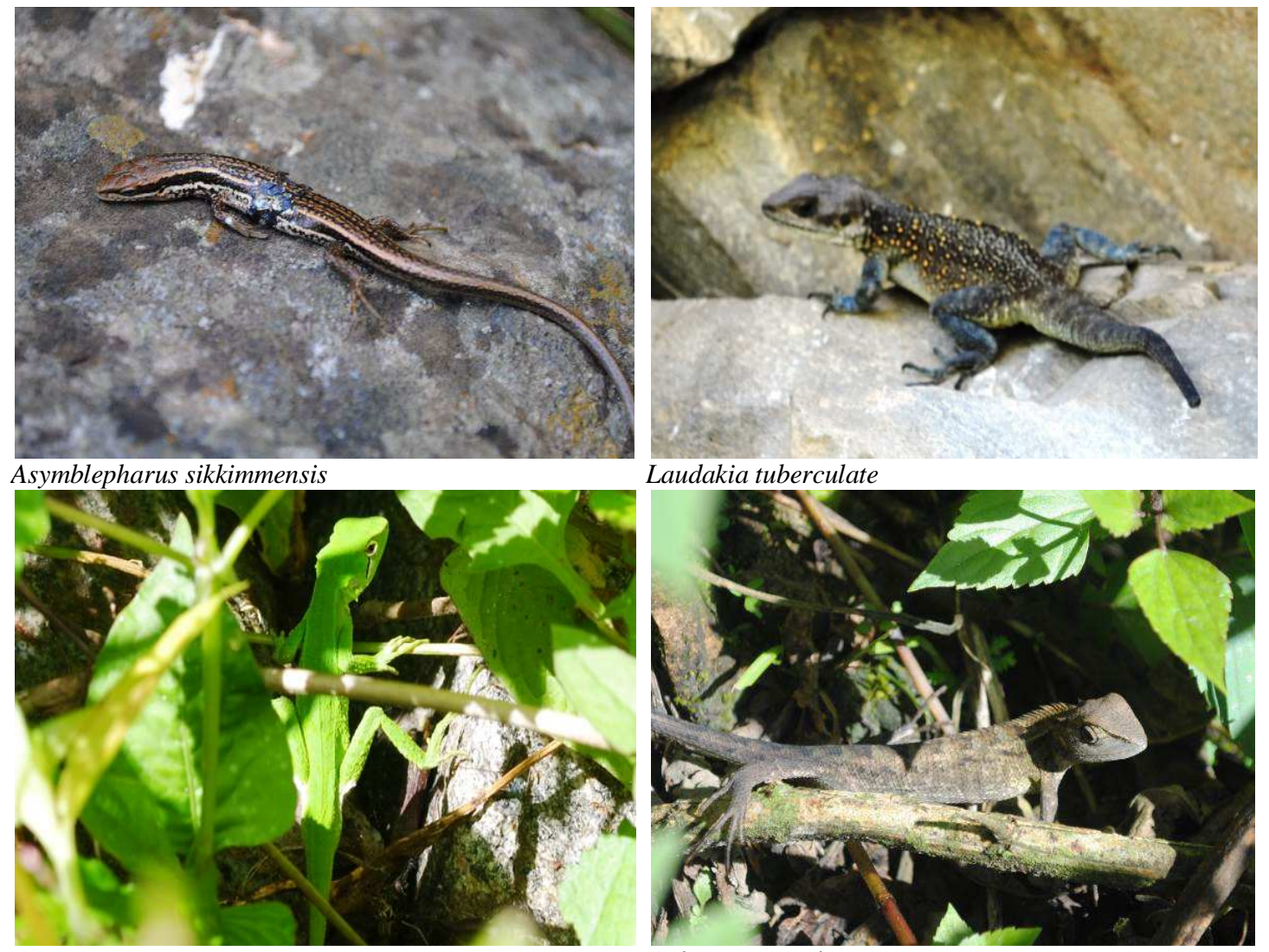

Laudakia tuberculate
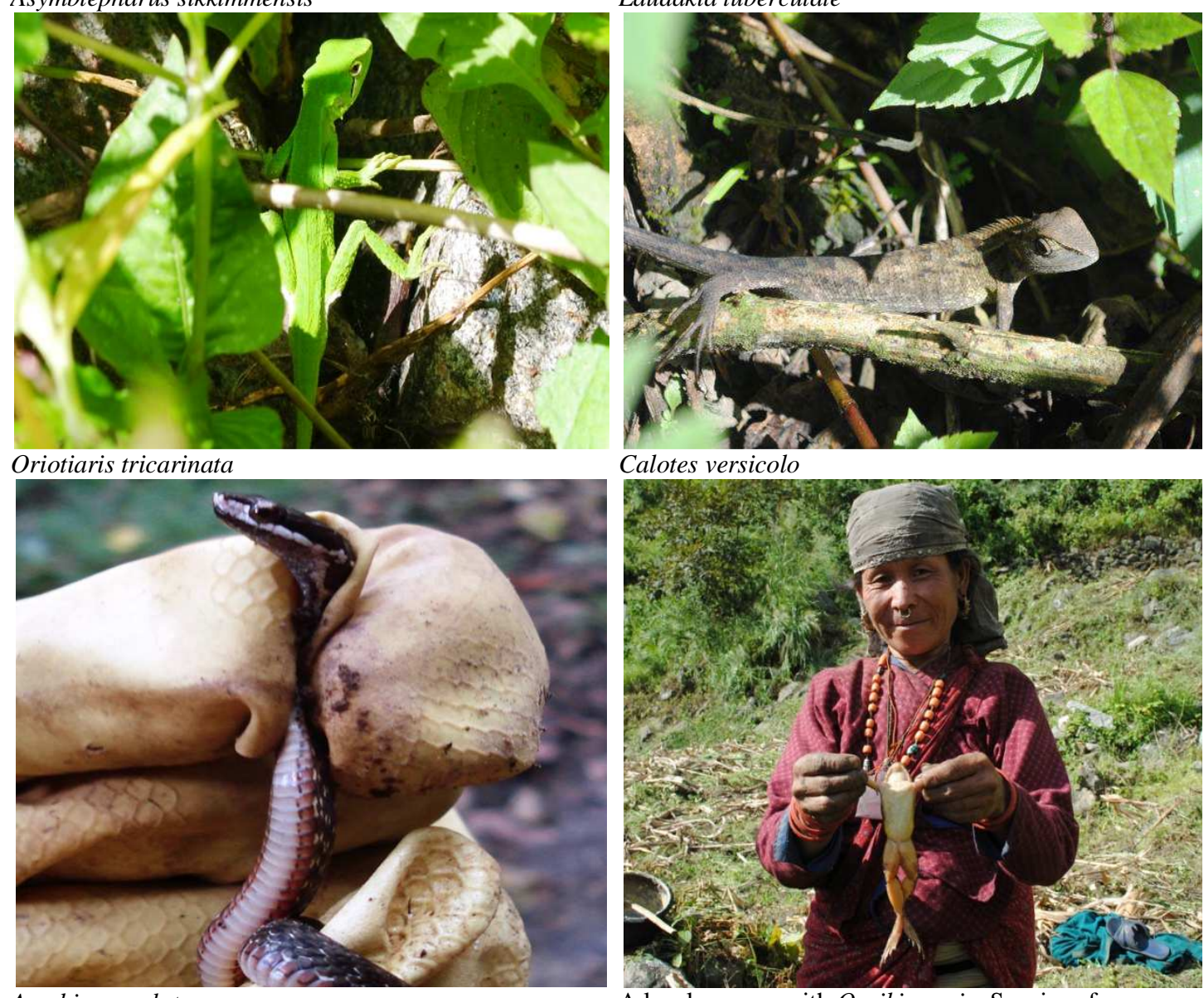

Calotes versicolo

Amphiesma platyceps

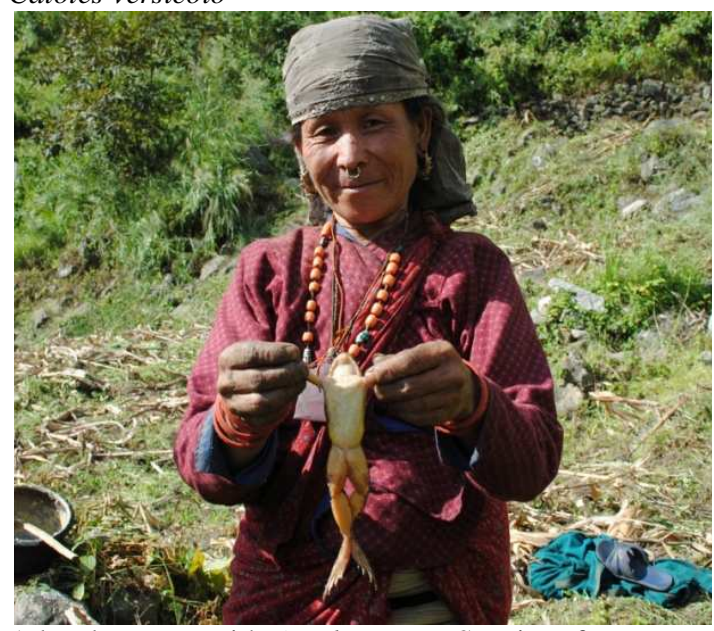

A local women with $O$. sikimensis: Species of

herpetofauna, particularly $O$. sikimensis are used as suppliment food by some local communities

Plate 2. Herpetofauna recorded from Manaslu Conservation Area. 
Table 1. Species record from secondary sources.

\begin{tabular}{|c|c|c|}
\hline SN Species & IUCN status & Source \\
\hline $1 \quad$ Paa blanfordii (Boulenger, 1882) & $\mathrm{LC}$ & Local people \\
\hline 2 Paa liebigii (Gunther, 1860) & $\mathrm{LC}$ & Local people \\
\hline 3 Trimeresurus albolabris (Gray, 1842) & Not listed & Local people \\
\hline 4 Oligodon erythrogaster Boulenger, 1907 & Not listed & Shah and Tiwari (2004) \\
\hline
\end{tabular}

Table 2. Amphibian species encountered during field survey.

\begin{tabular}{|c|c|c|c|}
\hline SN Species & Common name & $\begin{array}{l}\text { IUCN } \\
\text { status }\end{array}$ & $\begin{array}{l}\text { No. of individual } \\
\text { observed }\end{array}$ \\
\hline 1 Duttaphrynus himalayanus (Gunther, 1864) & Himalayan Toad & $\mathrm{LC}$ & 3 \\
\hline 2 Duttaphrynus microtympanum (Boulenger, 1882) & Small-eared toad & VU & 11 \\
\hline 3 Duttaphrynus stomaticus (Lutken, 1862) & Indus Valley toad & $\mathrm{LC}$ & 6 \\
\hline 4 Amolops formosus (Gunther, 1875) & Hill stream frog & $\mathrm{LC}$ & 5 \\
\hline 5 Ombrana sikimensis (Jerdon, 1870) & Frog & $\mathrm{LC}$ & 4 \\
\hline Total individuals & & & 26 \\
\hline
\end{tabular}

Table 3. Reptile species encountered during field survey.

\begin{tabular}{|c|c|c|c|}
\hline SN Species & Common name & $\begin{array}{l}\text { IUCN } \\
\text { status }\end{array}$ & $\begin{array}{l}\text { No. of individual } \\
\text { observed }\end{array}$ \\
\hline 1 Calotes versicolor (Daudin, 1802) & Common garden lizard & Not listed & 2 \\
\hline $\begin{array}{l}2 \text { Laudakia tuberculata (Hardwicke } \\
\text { and Gray, 1827) }\end{array}$ & Himalayan Rock Lizard & Not Listed & $>100$ \\
\hline 3 Oriotiaris tricarinata (Kastle et al., 2013) & Mountain Lizard & $\mathrm{LC}$ & 2 \\
\hline 4 Asymblepharus sikkimmensis (Blyth, 1853) & Sikkim skink & DD & 9 \\
\hline 5 Mabuya carinata (Schneider, 1801) & Keeled Indian Mabuya & $\mathrm{LC}$ & 7 \\
\hline 6 Boiga multifasciata (Blyth, 1861) & Many-banded tree snake & DD & 1 \\
\hline 7 Amphiesma platyceps (Blyth, 1854) & Himalayan keelback & Not listed & 3 \\
\hline Total Individuals & & & $>124$ \\
\hline
\end{tabular}
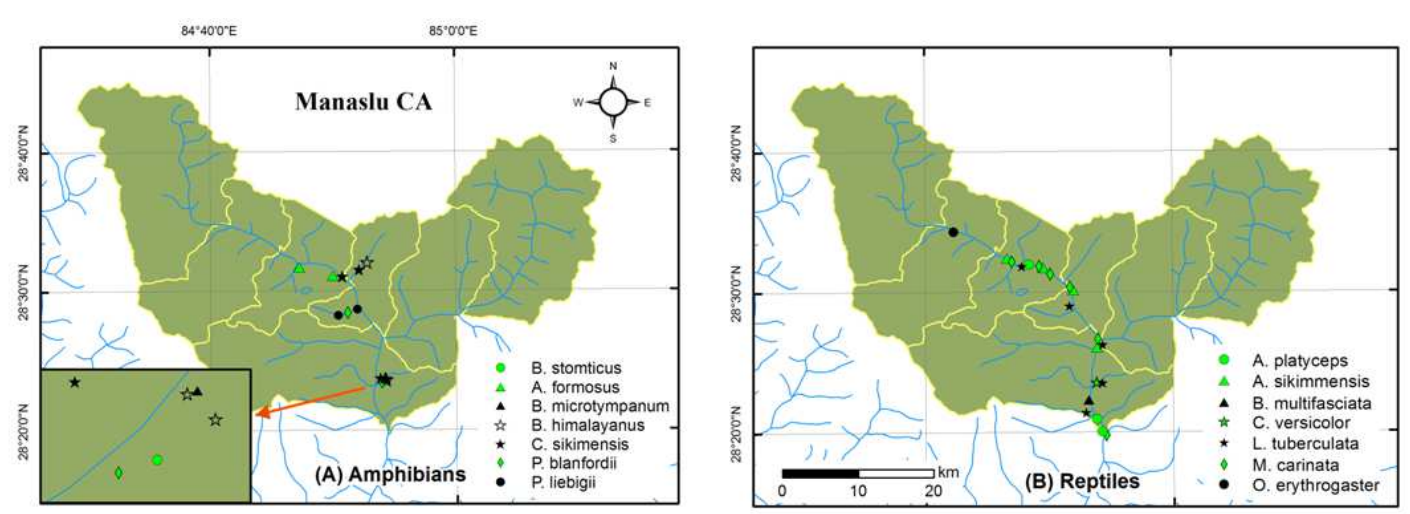

Figure 3. Spatial distribution recorded of (A) Amphibians and (B) Reptiles species in Manaslu Conservation Area (CA). 
Since, this study was carried out for short period for inventory purpose and thus, not possible to make a complete species occurrence and populations. Thus, detail study of herpetofaunal species in the region should be carried out based on the threats including population and habitat to get a regional perspective.

\section{Acknowledgement}

This work was possible due to financial and logistics support of Companions for Amphibians and Reptiles of Nepal (CARON). Our sincere thank goes to the National Trust for Nature Conservation for providing study permit in the Manaslu CA. We thank Prof. Karan Shah of Natural History Museum, Kathmandu for his guidance and supporting to identify species.

\section{References}

Arau jo, M.B., W. Thuiller and R.G. Pearson 2006. Climate warming and the decline of amphibians and reptiles in Europe. Journal of Biogeography 33: 1712-1728.

Behangana, M. and J. Arusi 2004. The distribution and diversity of amphibian fauna of Lake Nabugabo and surrounding areas. African Journal of Ecology 4: 6-13.

Blaustein, A.R. and D.B. Wake 1995. The puzzle of declining Amphibian populations. Scientific American 272: 52-58.

CEPF 2005. Ecosystem profile: Eastern Himalayas region. Critical Ecosystem Partnership Fund. Kathmandu, Nepal, 97 p.

Chaudhary, R.P. 1998. Biodiversity in Nepal- Status and conservation. Tec press Books, Bangkok.

Gardner, T.A. and E.B. Fitzherbert 2007. Spatial and Temporal Patterns of Abundance and Diversity of an East African Leaf Litter Amphibian Fauna. Biotropica 39: 105-113.

Gibbons, J.W., D.E. Scott, T.J. Ryan, K.A. Buhlmann, T.D. Tuberville, B.S. Metts, J.L. Greene, T. Mills, Y. Leiden, S. Poppy and C.T. Winne 2000. The global decline of Reptiles, Déjà $\mathrm{Vu}$ Amphibians. BioScience 50: 653-666.

ICIMOD and MOEST-GON 2007. Nepal biodiversity resource book: Protected areas, Ramsar sites, and World heritage sites. International Center for Integrated Mountain Development and Ministry of Environment, Science and Technology-Government of Nepal, nepalnature.com, Kathmandu.

Kiesecker, J.M., A.R. Blaustein and L.K. Belden 2001. Complex causes of amphibian population declines. Nature 410: 681-683.

Körner, C. 2002. Mountain biodiversity, its causes and function: An overview. In Mountain biodiversity: A global assessment (Körner, C. and E.M. Spehn eds.), Parthenon Publishing, New York. pp. 3-20.

Lafon, C.W. 2004. High biodiversity: An assessment of mountain biodiversity. Diversity and Distributions 10: 75-76.

Molur, S. 2008. South Asian amphibians: Taxonomy, diversity and conservation status. International Zoo Yearbook 42: 143-157.

NTNC2016. http://www.ntnc.org.np/project/manasluconservation-area-project.

Parra, G., R. Brown, J. Hanken, B. Hedges, R. Heyer, S. Kuzmin, E. Lavilla, S. Lötters, B. Pimenta, S. Richards, M.O. Rödel, R.O. de Sá and D. Wake 2007. Systematics and conservation. In Amphibian Conservation Action Plan (Gascon, C., J.P. Collins, R.D. Moore, D.R. Church, J.E. McKay and J.R. Mendelson III eds.), IUCN/SSC Amphibian Specialist Group, Gland, Switzerland and Cambridge, UK. pp. 45-48.

Rai, K.R., B.R. Subba and K.P. Limbu 2006. Review of the Anuran fauna (Amphibia: Anura) from Mustang, with description of four species. In Perspectives of animal ecology and Reproduction (Gupta, V.K. and A.K. Verma eds.), Vol. 5 (2008), Daya publication, Delhi. pp. 97-110.

Schleich, H.H. and W. Kastle 2002. Amphibians and reptiles of Nepal. A.R.G. Gantner Verlag Kommanditgesellsch. $1201 \mathrm{p}$.

Shah, K.B. and S. Tiwari 2004. Herpetofauna of Nepal: A conservation companion. IUCN Nepal, Kathmandu Nepal, Pages Viii +237.

Shah, K.B. 1995. Enumeration of the amphibians and reptiles of Nepal. Biodiversity Profiles Project, publication No. 2, HMG'S Department of National Parks and Wildlife Conservation, Kathmandu, Nepal.

Shrestha, T.K. 2001. Herpetology of Nepal: A study of amphibian and reptiles of Trans-Himalayan region of Nepal, India, Pakistan and Bhutan. Mrs. Bimala Shrestha, Kathmandu, Nepal. 280p. 